\title{
Periodic Assessment of Dry Matter Production and Nutritional Value of Millet Legumes Mix Fodder
}

\author{
M. Ayub $\cdot$ H. Abbas $\cdot$ M. Tariq $\cdot$ M. Tahir $\cdot$ \\ M. A. Nadeem • M. H. Siddiqui
}

Received: 25 May 2013/ Accepted: 17 July 2013/Published online: 28 August 2013

(C) NAAS (National Academy of Agricultural Sciences) 2013

\begin{abstract}
The intercropping of millet with legumes rich in protein was tested at 50,60 and 70th day of sowing for the dry matter and its nutritional value. The seeds of cluster bean, cowpea and sesbania were inter-seeded on the same day in millet. The preliminary analysis for forage quality of mixture indicated that the practice of intercropping appeared to be more successful for achieving the required nutritional value. Apparently, the successive delay in harvesting produced more dry matter and organic matter yield with the completion of biologic cycle of both the component crops. The significant loss of feeding value with respect to crude protein and ash of mixture was achieved with delayed harvesting. However, its negative impact was much low in millet-cluster bean and millet-cowpea mixture which sustained their protein contents over the sampling period. It is, therefore, suggested that mix cultivation of millet-legume, preferably sesbania, should be popularized among the dairy farmers for getting palatable and proteinaceous fodder.
\end{abstract}

Keywords Fodder $\cdot$ Dry matter $\cdot$ Feeding value $\cdot$ Millet $\cdot$ Legumes

\section{Introduction}

The livestock and crop mixed agriculture farming is commonly practiced by farmers, where livestock consume crops to fulfill their energy and nutritional requirements. The cereal crops are important forage source [10]. Due to low protein contents in cereal dry matter, the animals which rely on cereals for feeding requirement on long-term basis, develop protein deficiency and thus require a variety of protein rich supplements. In Pakistan, the principal and

M. Ayub · H. Abbas · M. Tahir - M. A. Nadeem Department of Agronomy, University of Agriculture, Faisalabad, Pakistan

e-mail: mayubuaf@hotmail.com

M. Tariq $(\bowtie)$

Barani Agricultural Training Institute, Dahgal, Rawalpindi,

Pakistan

e-mail: mtariq131@gmail.com

M. H. Siddiqui

Department of Agronomy, The University of Poonch,

Rawalakot, Pakistan cheapest source of animal feed is green forage, but its production and nutritional value is not satisfactory. There are several evidences in literature that had depicted considerable improvement in animal performance by ensuring the forages supply rich in protein and energy $[1,4]$. The protein rich supplements could be used as an additional source [9], but their high cost is a major concern in profitable livestock industry.

The millets are promising fodder in arid areas due to their drought tolerance capacity. Though their dry matter represents a small proportion of protein, the protein value can be boosted on sustainable basis through agronomic and crop improvement approaches. Although, dry matter production of legume is poor but it is superior for forage quality [19]. The mixing of legumes in cereals may improve the protein proportion through their significant biomass contribution. The legumes being rich in protein, their inclusion in cereal stand is applicable option to compensate the protein deficiency [12] and hence, this strategy is helpful to reduce the livestock feed expenditure. The presence of legumes in cereals stand during joint growth period facilitates the cereals growth through improved nitrogen supply [22] and 
thus, increases nutritional value [3, 15]. This strategy is widely practiced over tropics, sub humid and rain-fed areas of the globe [2, 8, 13, 14].

The crops growth is series of events and transition within growth stages is accompanied by changes in physiologic and morphological traits to reach its destiny which has direct or indirect influence over forage nutritional value $[16,24]$. For the grains, crop is mostly allowed to attain maturity, but for forage early harvesting of crop at vegetative growth is practiced. Certain quality constituents are built up and others are dropped with the advancement of growth. The present investigation was aimed to recognize the optimum harvesting time and legume association effect on forage production and quality of millet.

\section{Materials and Methods}

The present investigation was carried out at the Agronomic Research Area, University of Agriculture, Faisalabad $\left(31^{\circ} 40^{\prime \prime} \mathrm{N}, 73^{\circ} 11^{\prime \prime} \mathrm{E}\right)$ during kharif season on 26th July 2010. The seed bed was prepared with normal soil preparation tools and millet seeds were sown with hand drill method in $70 \mathrm{~cm}$ spaced rows. The soil was irrigated before sowing and its preparation started on 8th day of irrigation. The seeds of legumes were sown at recommended seeding density on the same day by replacing the single rows of millet at $30 \mathrm{~cm}$ away using a seed rate of $5 \mathrm{~kg} \mathrm{ha}^{-1}$. Thus, each experimental plot was equally covered by millet and legumes. The performance of millet for forage yield and quality was evaluated with legumes (cluster bean, cowpea, and sesbania) and harvesting variables $(\mathrm{H} 1=50, \mathrm{H} 2=60$ and $\mathrm{H} 3=70$ DAS) in randomized complete block design (factorial arrangement). The experiment was replicated thrice measuring a net plot size of $3.60 \times 6 \mathrm{~m}$. Thus, individual plot has 6 rows, each of legumes and millet. The crop was supplied with NP fertilizer at $60 \mathrm{~kg} \mathrm{ha}^{-1}$ each in the form of urea and single superphosphate, respectively at sowing. Both the fertilizers were incorporated in soil during seed bed preparation. The experimental plots were flood irrigated to keep the soil moisture to optimum level. The emerging weeds were removed manually at 15 th day of sowing (DAS). The plant agronomic traits, dry matter yield and its composition were measured separately at each harvest. The average plant height and stem diameter were recorded from ten randomly selected plants. The plant height was taken from tape measured method from ground surface to the highest leaf tip and stem diameter was measured at bottom, middle and top of the plants. The area of one meter square was harvested at prescribed schedule to have dry matter yield of millet and legumes. The dry matter yield was derived from the proportion of dry matter in fresh plants. A part of sample was preserved in grind form in polythene bags for its chemical composition. The proximate analysis of forage sample was carried for crude protein and ash [6], and crude fiber [25]. The organic matter was determined by subtracting the ash contents from dry matter. The collected data were statistically analyzed by using Fisher's analysis of variance technique and the significance of mean values was evaluated by least significance test (LSD) at $5 \%$ probability level [23].

\section{Results and Discussion}

\section{Dry Matter Yield of Millet and Legumes Mixture}

The dry matter yield and its related agronomic traits increased by extending the harvesting and thus minimum and maximum values for these attributes were recorded at 50th and 70th days of sowing, respectively. This happens because plots harvested at the end got more time for utilization of growth factors and it gave higher values over earlier harvesting. It can be concluded from these results that the growth continued up to 70 days after sowing, and the maturation was not till completed. Similar effect of harvesting was observed on the dry matter yield of legumes. The increase in forage yield with delayed harvesting has also been reported by other workers [5, 7, 17].

Likewise, the effect of harvesting time was also studied on the dry matter yield and agronomic traits of millet by the type of legume intercropped. Among the three legumes studied, sesbania seems to be most suitable legume for millet intercropping for maximum plant length, stem thickness, leaf area development and finally dry matter yield. It showed the additive and complementary effects of millet-sesbania intercropping due to which it produced superior figures for dry matter over rest of the treatments. The interseeding of cluster bean in millet had poor performance over the tested intercropping systems. The millet-sesbania combination out crossed the other combinations for dry matter yield at all sampling period. Therefore, forage growers strictly follow this intercropping system for ensuring better yield irrespective of time of harvesting. The interface of legumes for dry matter yield improvement of millet is not much important at earlier harvesting and became prominent at final harvesting for the reason of time period of joint growth. The sesbania intercropping and late harvesting of millet resulted in maximum dry matter yield through supportive yield parameters. The dry matter from millet-cluster bean was not statistically different from millet-cowpea at 50th days of growth but the differences were more prominent at 60 th day. The improved yield may be explained in term of efficient resource utilization like light, moisture, nutrients and soil nitrogen enrichment through nitrogen fixation. The erect and fast growth of sesbania received sufficient light with millet and both the components almost equally contributed to be 


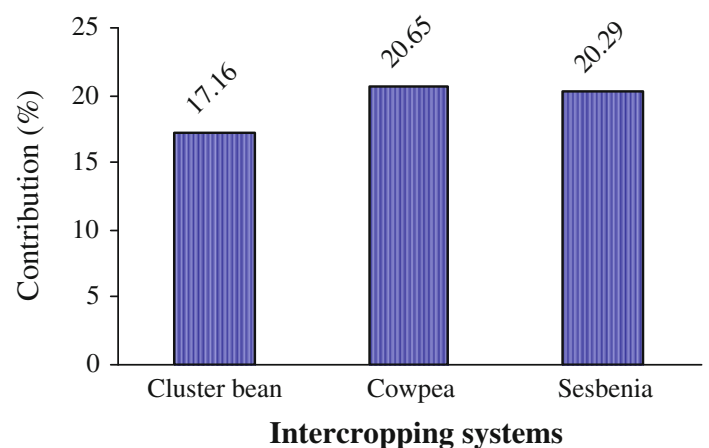

Fig. 1 Percent contribution of legumes to total dry matter yield

superior over other plots. The tall canopy of millet which shaded the underlying cowpea during their overlapping growth period resulted in yield reduction of mix forage. The behavior of legume crops did not change and hence the legume proved superior throughout the sampling period. The significant differences reported [20,21] in dry matter yield from sorghum-legume intercropping, confirm our findings. In dry matter yield, the share of cluster bean was the lowest $(17.16 \%)$ whereas cowpea and sesbania constituted 20.65 and $20.29 \%$, respectively, in mixed millet-legume cropping (Fig. 1).

\section{Forage Quality of Millet-Legumes Mixture}

The forage feeding value declined with the subsequent delay in harvesting, mainly from protein and organic matter reduction and crude fiber deposition. Both the millet and legume partners undergo nutritional value loss through an increment in cell wall contents associated with further developmental stage, particularly from leaf loss. The fiber deposition in stems proceeds with advancement of growth with the objective to support flowering head. Toward maturity, the stem elongation is accomplished with stiffness and therefore, contribution of stem for crude fiber is higher at later stages. The forage samples taken at younger growth were leafy and thus proved superior over later stages. By regulating the time of interseeding to synchronize the onset of legumes flowering to best harvesting time may be helpful for further improvement of fodder quality of mixed millet-legume crop [18] Table 1, 2.

The legumes intercropping produce a range of quality fodder mainly from enhanced protein in the total dry matter. The millet-sesbania mixture was significantly higher for crude protein and ash over the other combinations. At the same time, its dry matter is also rich in crude fiber, mainly attributed to its woody growth habit where it has to support a larger stem. At the same time, it had produced the lowest organic matter value over rest of the treatments. The organic matter contents in the dry mass were reduced up to second sampling after which it became

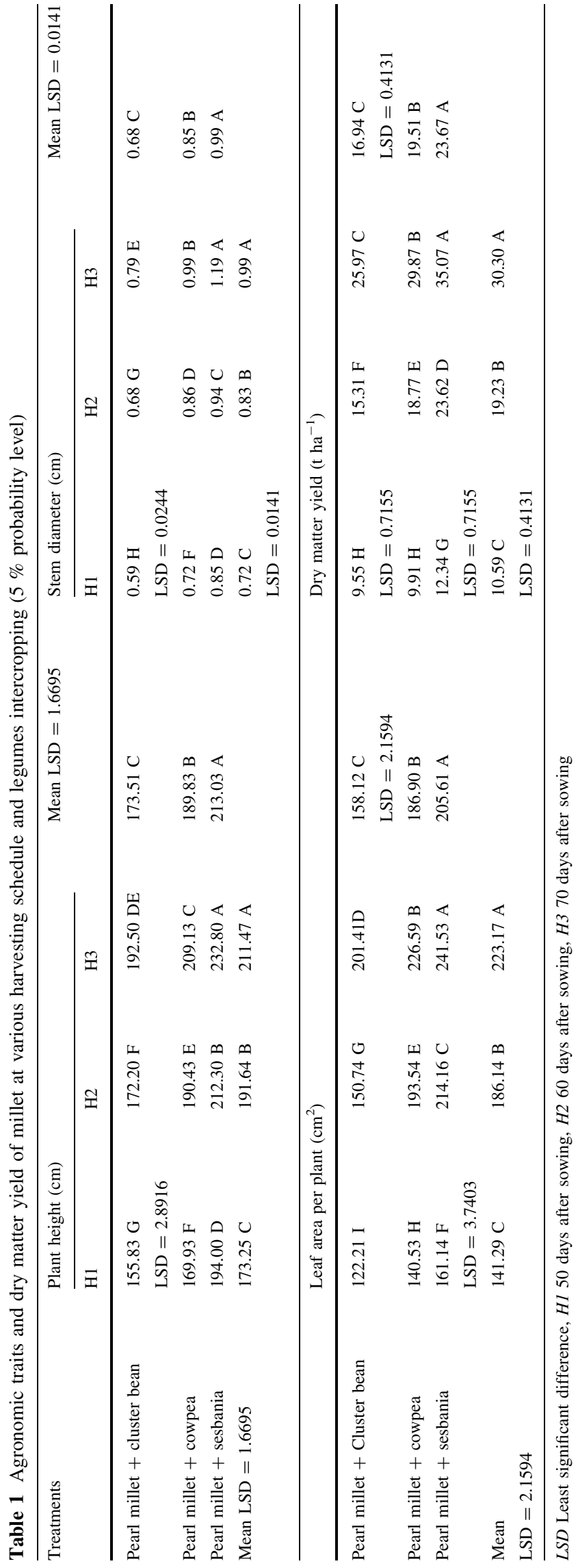


Table 2 Dry matter yield of legumes ( $\mathrm{t} \mathrm{ha}^{-1}$ ) and their mixture with millet (5\% probability level)

\begin{tabular}{|c|c|c|c|c|c|c|c|c|}
\hline \multirow[t]{2}{*}{ Treatments } & \multicolumn{3}{|c|}{$\begin{array}{l}\text { Dry matter yield of legumes } \\
\left(\mathrm{t} \mathrm{ha}^{-1}\right)\end{array}$} & \multirow[t]{2}{*}{ Mean LSD $=0.3174$} & \multicolumn{3}{|c|}{$\begin{array}{l}\text { Dry matter yield of mixture } \\
\left(\mathrm{t} \mathrm{ha}^{-1}\right)\end{array}$} & \multirow[t]{2}{*}{ Mean LSD $=0.5118$} \\
\hline & $\mathrm{H} 1$ & $\mathrm{H} 2$ & $\mathrm{H} 3$ & & $\mathrm{H} 1$ & $\mathrm{H} 2$ & $\mathrm{H} 3$ & \\
\hline Pearl millet + cluster bean & $\begin{array}{l}2.29 \mathrm{~F} \\
\mathrm{LSD}=.5497\end{array}$ & $3.71 \mathrm{E}$ & $4.55 \mathrm{CD}$ & $3.51 \mathrm{C}$ & $11.84 \mathrm{H}$ & $19.02 \mathrm{E}$ & $30.52 \mathrm{C}$ & $20.46 \mathrm{C}$ \\
\hline Pearl millet + cowpea & $4.08 \mathrm{DE}$ & $5.08 \mathrm{C}$ & $6.12 \mathrm{~B}$ & $5.08 \mathrm{~B}$ & $13.99 \mathrm{G}$ & $23.85 \mathrm{D}$ & $35.99 \mathrm{~B}$ & $24.60 \mathrm{~B}$ \\
\hline Pearl millet + sesbania & $4.63 \mathrm{C}$ & $5.78 \mathrm{~B}$ & $7.79 \mathrm{~A}$ & $6.06 \mathrm{~A}$ & $\begin{array}{l}16.70 \mathrm{~F} \\
\mathrm{LSD}=0.8865\end{array}$ & $30.10 \mathrm{C}$ & $42.84 \mathrm{~A}$ & $29.87 \mathrm{~A}$ \\
\hline $\begin{array}{l}\text { Mean } \\
\mathrm{LSD}=0.3174\end{array}$ & $3.66 \mathrm{C}$ & $4.85 \mathrm{~B}$ & $6.15 \mathrm{~A}$ & & $\begin{array}{l}14.17 \mathrm{C} \\
\mathrm{LSD}=0.5118\end{array}$ & $24.32 \mathrm{~B}$ & $36.44 \mathrm{~A}$ & \\
\hline
\end{tabular}

LSD Least significant difference, $H 150$ days after sowing, $H 260$ days after sowing, $H 370$ days after sowing

Table 3 Proximate analysis of dry matter of legumes and millet mixture (5\% probability level)

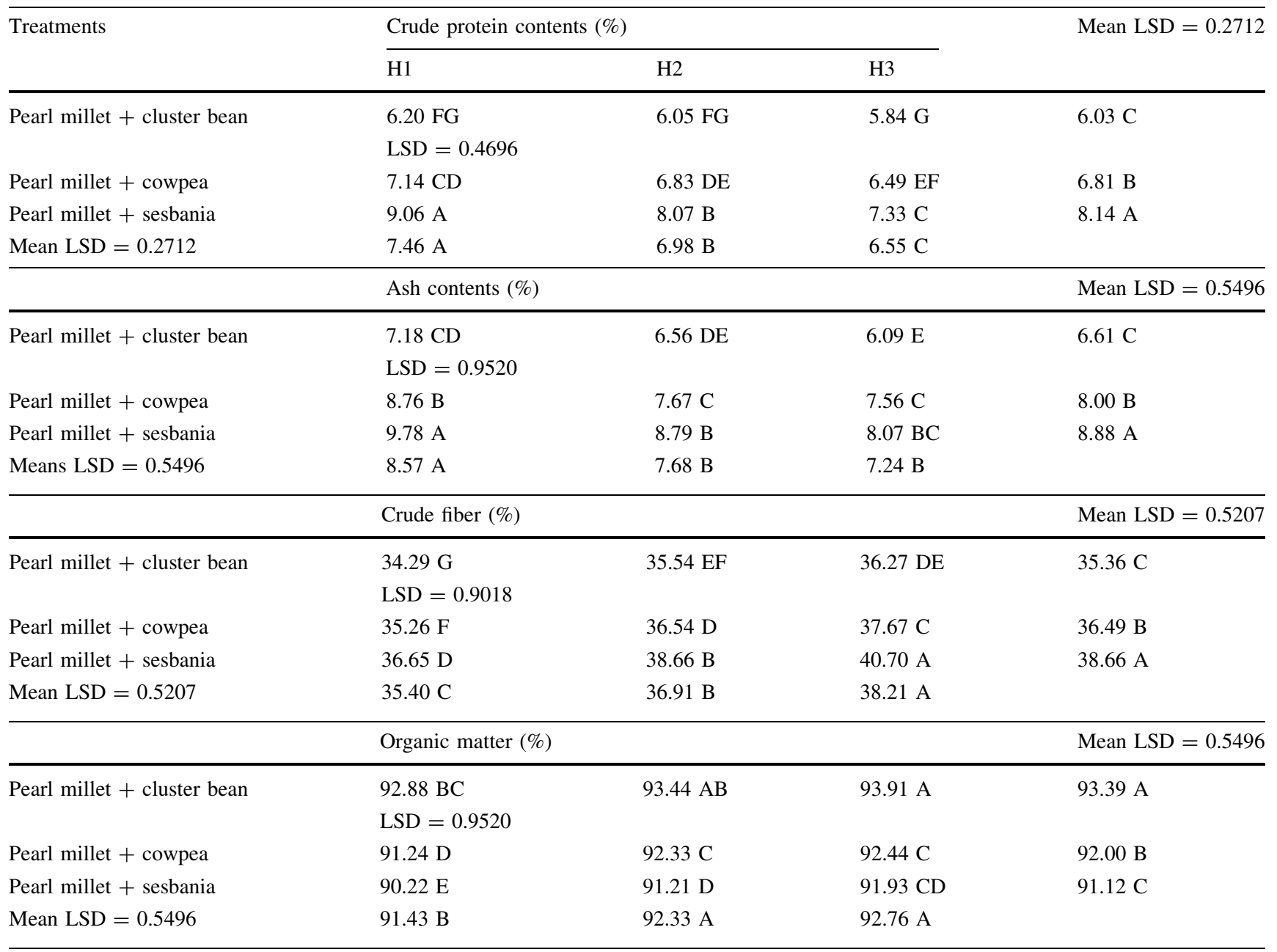

LSD Least significant difference, $H 150$ days after sowing, $H 260$ days after sowing, $H 370$ days after sowing

stable. The nutritional quality of forage from milletlegume mixtures deteriorated at subsequent delay in harvesting time. However, the intensity and severity of deterioration was based on the type of legume intercropped. The protein contents in dry matter from millet-sesbania were significantly reduced at every delay in harvesting, whereas mixture from cluster bean and cowpea sustained their protein value over the harvesting period (Table 3). The variation in forage quality deterioration of the mixed fodder at successive delay would make an important 
implication. If the grower is intended to harvest the crop at full maturity, then millet-cowpea and millet-cluster bean should be preferred. The combination will reduce the risk of forage quality loss associated with delayed harvesting. The mixture from legumes and millet would provide inexpensive protein and energy source, and thus animals consuming mix forage would have better performance. The superior nutritional profile of legumes over cereals suggested that animal would get more forage at similar maturity stage. The positive correlation of forage quality to leaf area suggested that the crop should be harvested before the commencement of significant leaf loss. Significant forage improvement was reported when maize was grown in association with legumes [11].

\section{Conclusions}

The yield and quality of mix forage were based on time of harvesting and legume used for intercropping. Simultaneously planted sesbania in millet stand and early harvesting ensure the maximum feeding value especially from higher ash and crude protein followed by millet-cowpea mixture. Thus, it provides inexpensive home grown quality protein source for animals. However, the earlier harvesting reduced the dry matter and organic matter yield but it is up to the grower whether to choose quality or quantity or a compromise between two.

\section{References}

1. Adesogan AT, Salawu MB, Deaville ER (2000) The effect of pea to wheat ratio and harvest date on the voluntary feed intake, in vivo digestibility and nitrogen retention of pea wheat bi-crop silage by sheep. In: Proceedings of the British Society of Animal Science, $\mathrm{p} 82$

2. Agegnehu G, Ghizam A, Sinebo W (2006) Yield performance and land use efficiency of barley and faba bean mixed cropping in Ethopian high lands. Eur J Agron 25:202-207

3. Ahmad AUH, Ahmad R, Mahmood N, Tanveer A (2007) Performance of forage sorghum intercropped with forage legumes under different planting patterns. Pak J Bot 39(2):431-439

4. Anil L, Park J, Phipps RH (2000) The potential of forage-maize intercrops in ruminant nutrition. Anim Feed Sci Technol 86(3):157-164

5. Ansar M, Ahmed ZI, Malik MA, Nadeem M, Majeed A, Rischkowsky BA (2010) Forage yield and quality potential of winter cereal-vetch mixtures under rainfed conditions. Emir J Food Agric 22:25-36

6. AOAC (1999) Official methods of analysis, 16th edn. Association of Official Analytical Chemists, Wahington DC

7. Bonjar G, Lee HC (2003) Intercropped wheat (Triticum aestivum L.) and bean (Vicia faba L.) as a whole-crop forage: effect of harvest time on forage yield and quality. Grass Forag Sci 58:28-36

8. Dahmardeh M, Ghanbari A, Syasar B, Ramrodi M (2009) Intercropping maize (Zea mays L.) and cowpea (Vigna unguiculata L.) as a whole-crop forage: effects of planting ratio and harvest time on forage yield and quality. J Food Agric Environ 7(2):505-509

9. Eskandari H, Ghanbari A, Javanmard A (2009) Intercropping of cereals and legumes for forage production. Not Sci Biol $1(1): 7-13$

10. Ghanbari-Bonjar A (2000) Intercropped wheat (Triticum aestivum) and bean (Vicia faba L.) as a low-input forage. PhD thesis, Wye College, University of London

11. Ibrahim M, Ayub M, Tanveer A, Yaseen M (2012) Forage quality of maize and legumes as monocultures and mixtures at different seed ratios. J Anim Pl Sci 22(4):987-992

12. Ibrahim M, Rafiq M, Sultan A (2006) Green fodder yield and quality evaluation of maize and cowpea sown alone and in combination. J Agric Res 44(1):15-21

13. Karadag Y (2004) Forage yields, seed yields and botanical compositions of some legume-barley mixtures under rainfed condition in semi-arid regions of Turkey. Asian J Plant Sci 3(3):295-299

14. Mafongoya PL, Mugendi DN, Jama B, Waswa BS (2003) Maize based cropping systems in the sub humid zone of east and southern Africa. In: Gichuru MP, Bationo A, Bekunda MA, Goma HC, Mafongoya PL, Mugendi DN, Murwira HK, Nandwa SM, Nyathi P, Swift MJ (eds) Soil fertility management in Africa: A regional perspective. Academy Science Publishers with TSBFCIAT, Nairobi, pp 73-122

15. Moreira N (1989) The effect of seed rate and nitrogen fertilizer on the yield and nutritive value of oat-vetch mixture. J Agric Sci 112:57-66

16. Nykanen A, Jauhiainen L, Rinne M (2009) Biomass production and feeding value of whole-crop cereal-legume silages. Agron Res 7:684-690

17. Ram SN, Suresh G, Singh KK (2007) Effect of planting geometry and cutting management on productivity, quality and economics of mixed pasture under rainfed conditions. Ind $\mathrm{J}$ Agron $52: 251-256$

18. Reta Sanchez DG, Espinosa Silvia JT, Palomo Gil A, Serrato Corona JS, Cueto Wong JA, Gaytan Mascorro A (2010) Forage yield and quality of intercropped corn and soybean in narrow strips. Span J Agric Res 8(3):713-721

19. Ross SM, King JR, Donovan JT, Spaner D (2004) Intercropping berseem clover with barley and oat cultivars for forage. Agron J 96:1719-1729

20. Sarwar H(2006) Effect of planting geometry and forage legume intercropping system on the yield and quality of forage sorghum (Sorghum bicolor L.). MSc. (Hons) thesis, Department of Agronomy, University of Agriculture, Faisalabad, Pakistan

21. Shafaqat M (2010) Effect of different sowing techniques and legumes intercropping systems on yield and quality of sorghum (Sorghum bicolor L.) forage. MSc. (Hons) thesis, Department of Agronomy, University of Agriculture, Faisalabad, Pakistan

22. Shen QR, Chu GX (2004) Bi-directional nitrogen transfer in an intercropping system of peanut with rice cultivated in aerobic soil. Biol Fert Soils 40:81-87

23. Steel RGD, Torrie JH, Dickey DA (1997) Principles and procedures of statistics, a biometrical approach, 3rd edn. McGraw Hill, Inc. Book Co, NY, pp 352-358

24. Tariq M, Ayub M, Elahi M, Ahmad AH, Chaudhary MN, Nadeem MA (2011) Forage yield and some quality attributes of millet (Pennisetum americannum L.) hybrid under various regimes of nitrogen fertilization and harvesting dates. Afr J Agric Res 6:3883-3890

25. Van Soest PJ, Robertson JB, Lewis BA (1991) Methods for dietary fibre, neutral detergent fibre, and nonstarch polysaccharides in relation to animal nutrition. J Dairy Sci 74:3583-3597 